\title{
Novi mediji (kao alat) u nastavi: Djeca i folklor
}

Stručni rad_DOI 10.22522/cmr20190149 _ primljeno 19. siječnja 2018.

UDK: 398(497.5):372.4

$004: 316.774(072)$

\section{Lina Malek}

Hrvatski studiji (doktorandica), Zagreb, Hrvatska.

E-adresa: lina.malek@gmail.com

\section{Sažetak}

Hrvatska je zemlja bogata kulturnom baštinom. Narodne nošnje, pjesme i plesovi mogu se upoznati u muzejima, stručnoj literaturi i kroz djelatnost kulturno-umjetničkih društava. No, razvijena tehnologija uvela je nove oblike predstavljanja i očuvanja folklornih sadržaja. Tako, primjerice, djeca u nižim razredima osnovne škole, osim uz učitelje i udžbenike iz Glazbene kulture, tradicionalne dječje pjesme mogu poslušati na YouTubeu. Stoga je cilj rada potaknuti usvajanje znanja o hrvatskom folkloru uz pomoć novih medija kao alata i kao sredstva za edukaciju u osnovnim školama, na temelju teorijskog i praktičnog aspekta. Radom se utvrdilo da postoje stručni tekstovi i upute o upotrebi medija u nastavi, no nema tekstova usmjerenih isključivo na povezivanje nastave, medija i folklora. Osim što se osvrće na dosadašnja teorijska stajališta, kao i na primjere primjene medija u nastavi, autorica opisuje vlastiti projekt koji je ostvarila u jednoj zagrebačkoj osnovnoj školi čime nastoji potaknuti na upotrebu medija u obrazovanju o kulturi.

Ključne riječi: osnovnoškolska nastava, hrvatski folklor, novi mediji, pozitivne strane novih medija 


\section{Uvod}

Svi članovi društvene zajednice trebali bi imati priliku upoznati se s medijima, naučiti kako ih pravilno koristiti i razviti kritički pristup. Osobito su važni djeca i mladi jer oni rastu s medijima, koji ih nerijetko i odgajaju. Škole su mjesto obrazovanja, informiranja i zabave, a tomu služe i mediji. Kada se te tri medijske funkcije spoje, dobiva se kvalitetna platforma za dječji razvoj i kreativnost. Kulturna je baština važan dio društvenoga identiteta zajednice. Tradicijska kultura prenosi se s koljena na koljeno i zato je potrebno poznavati je odmalena.

Brojni znanstveni i stručni članci bave se kulturnom baštinom (folklorom) i učenjem o njoj u obrazovnim institucijama od najmlađe životne dobi (Češi, Barbaroša-Šikić, 2008; Čukelj, 2009; Dobrota, Kuščević, 2008; Galinec i sur., 2012; Kostović-Vranješ, 2015; Kušćević, 2015; Letina, Bertić, 2010; Pregrad, 2006; Seme-Stojnović, Vidović, 2012), kao i ulogom medija u odgoju i obrazovanju djece (Košir, Zgrabljić, Ranfl, 1999; Ilišin, Bobinac, Radin, 2001; Nadrljanski, Nadrljanski, Bilić, 2007; Rončević, Blažič, 2009; Ciboci, Kanižaj, Labaš, 2011; Uldrijan, 2011; Blanuša Trošelj, Srića, 2014; Osmančević, 2016), no nedostaje radova koji povezuju sve te teme - djecu, folklor i medije. Stoga je ovaj rad važan jer na jednom mjestu opisuje kako uspješno spojiti tradiciju, nove tehnologije i djecu. Cilj je rada potaknuti usvajanje znanja o hrvatskom folkloru uz pomoć novih medija kao alata i sredstva edukacije u osnovnim školama, na temelju teorijskog i praktičnog aspekta. Osim što su iznesena relevantna mišljenja stručnjaka o korištenju medija u nastavnom procesu, prikazani su i primjeri implementiranja medija u nastavi. Opisuje se i autorski volonterski projekt koji je proveden u OŠ Sveta Klara u Zagrebu u školskoj godini 2015./2016. te se daju prijedlozi za stjecanje i usvajanje znanja o tradicijskoj baštini uz pomoć novih medija u zabavno-edukativnom okruženju.

\section{Novi mediji un mastavi}

Prije dvadesetak godina Manca Košir, Nada Zgrabljić Rotar i Rajko Ranfl (1999, str. 15) utvrdili su da su masovni mediji sveprisutni. I danas su oko nas, u još većem broju. Goruća tema 21. stoljeća i uznapredovale tehnologije je medijska kultura i oblici koje ona podrazumijeva. Veliki je broj stručnih tekstova o upotrebi medija u nastavi. Tom su se temom u Hrvatskoj bavili Nada Zgrabljić Rotar i Karmen Erjavec (2000), Nada Zgrabljić 
Rotar (2005, 2011, 2017), Mila Nadrljanski, Đorđe Nadrljanski i Mirko Bilić (2007), Anita Rončević i Marjan Blažič (2009), Jadranka Žderić (2009), Lana Ciboci, Igor Kanižaj i Danijel Labaš (2011), Leali Osmančević (2016) i drugi. Neupitno je da mediji mogu imati višestruku korist za djecu i mlade ako ih se upotrebljava na pravilan i pozitivan način. Tome prethodi kvalitetna edukacija i poticanje kritičkog promišljanja o medijima, tj. sustavni medijski odgoj koji danas nedostaje u hrvatskom obrazovnom sustavu. Mila Nadrljanski, Đorđe Nadrljanski i Mirko Bilić (2007) u članku o digitalnim medijima u obrazovanju zaključili su da mediji mogu imati pozitivne učinke na djecu, u čemu se očituje važnost upotrebe novih tehnologija u školama: „Širenjem digitalnih medija u profesionalnom i privatnom životu pojačan je zahtjev za korištenjem tih tehnologija i u obrazovanju. Obrazloženje toga zahtjeva zasniva se na općoj društvenoj važnosti, na budućoj profesionalnoj relevantnosti digitalnih medija, na pedagoškim učincima $u$ poboljšanju učenja i rezultata učenja te na potencijalu promjena koje bi mogle nastupiti u institucijama kao što su škole.“ (Nadrljanski, Nadrljanski, Bilić, 2007, str. 529)

Autori tvrde da se „digitalizirane informacije mogu lakše montirati potpomognute slikom, animacijom i zvukom, a one istovremeno djeluju na više osjetila dajući potpunu informaciju. (...) Pomoću raznovrsnih medija omogućen je šarolik transfer znanja, a pojava interaktivnih multimedijalnih sustava unaprjeđenje je u odnosu na dosadašnje obrazovne softvere.“ (Nadrljanski, Nadrljanski, Bilić, 2007, str. 528) Ističu i da veliku ulogu imaju nastavnici koji moraju biti osposobljeni za korištenje digitalnih medija, kako bi bila ostvarena integracija medija u nastavnim procesima (Nadrljanski, Nadrljanski, Bilić, 2007, str. 531). Kada pišu o iskustvima nastavnika, tvrde da „na digitalne medije se u principu ne gleda kao na nužan preduvjet dobre nastave, već više kao na potencijal koji doprinosi obogaćivanju i poboljšanju nastave i koji treba iskoristiti“ (Nadrljanski, Nadrljanski, Bilić, 2007, str. 534-535). Autori dodaju da bi obrazovna svakodnevica trebala biti ispunjena digitalnim medijima, pri čemu temelj treba biti na razumijevanju korelacije između tehnike i kulture (Nadrljanski, Nadrljanski, Bilić, 2007, str. 531-532).

U brošuri o medijima kao učiteljima Danijel Labaš, Lana Ciboci i Igor Kanižaj (2015, str. 13) detaljno opisuju kako tehnologija pomaže u proširenju gradiva koje djeca uče na nastavi: „Mediji nam pomažu proširiti gradivo koje smo naučili u školi. Ako učimo nešto teško, mediji nam uz pomoć slike, zvuka i videa mogu olakšati i pojednostaviti učenje. Mediji nam omogućuju pripremiti školske zadaće i projekte na zabavan način koji će se svima svidjeti (npr. prezentacije u Power Pointu).... Internet je najbolje pomoćno sredstvo 
u pojašnjenju nastavnog gradiva, ali i kao izvor dodatnih materijala za učenje: vježbi, primjera ili proširenje gradiva sa sata.“ Leali Osmančević (2016, str. 79) je napomenula da mediji imaju sve veću ulogu na svim razinama odgojno-obrazovnih institucija $\mathrm{s}$ obzirom na njihovu multifunkcionalnost, što su naglasili i Nadrljanski, Nadrljanski i Bilić (2007). Osmančević (2016, str. 79) piše da se medije upotrebljava „kao sredstvo rada među učenicima, kao alat za pripremu nastavnih materijala te kao jednu od nastavnih tema unutar školskog kurikuluma“. Osvrće se i na novija istraživanja koja su pokazala da „korištenje različitih medija u obrazovanju može poboljšati kvalitetu učenja iako sustavno korištenje više tehnologija istovremeno dugoročno ne uzrokuje veću kvalitetu učenja kod djece osnovnoškolske dobi“ (Fisch i sur., 2016, str. 238 prema Osmančević, 2016). Autorica spominje da su nastavnici Hrvatskoga jezika otvoreni za upotrebu raznovrsnih medija kada podučavaju o medijskoj kulturi, ali da je pritom važno znati koliko su naše učionice (ne)opremljene za takav oblik učenja (Ciboci, Osmančević, 2015, str. 133-134 prema Osmančević, 2016).

U Nastavnome planu i programu za osnovu školu stoji: „Osnovna škola predstavlja obveznu razinu odgoja i obrazovanja, kojoj je funkcija osiguravanje stjecanja širokoga općeg odgoja i obrazovanja. S općim odgojem i obrazovanjem učenici dobivaju temeljna znanja potrebna čovjeku za život, otvara im se mogućnost daljnjega školovanja, postiže se jednakost odgojno-obrazovnih mogućnosti, a s obvezom polaženja osnovne škole sprječava se njihovo odgojno--obrazovno diskriminiranje i društveno marginaliziranje.“ (Ministarstvo znanosti, obrazovanja i športa, 2006, str. 10) Aktualni je Nastavni plan pisan prije desetak godina, a tehnologija je u međuvremenu izrazito napredovala. ${ }^{1}$ Stoga je važno uskladiti nastavni program s današnjim mogućnostima i okolnostima koje nude društvo i tehnologija. Sukladno tome, u sve predmete trebaju se uvesti mediji kao predmet učenja ${ }^{2}$, zatim kao nastavno pomagalo te medije u praktičnom radu s djecom, pri čemu se

1 U 2019. i dalje je na snazi Nastavi plan i program za osnovne škole (Glazbena kultura) iz 2006. godine, u čemu i jest problem budući da se u 13 godina tehnologija razvila i da je potrebno što prije Plan i program uskladiti s „digitalnim“vremenom u kojem djeca žive. Postoji Nacionalni okvirni kurikulum, no tu se ne opisuje Glazbena kultura na ovakav način kao u Nastavnom planu iz 2006.

2 Veliki broj stručnjaka smatra da medijsku kulturu, tj. medijski odgoj, treba uvesti i kao zaseban nastavni predmet (Ciboci, 2012), a ne samo kao dio nastave određenoga predmeta (u ovome trenutku o medijima se uči u sklopu predmeta Hrvatski jezik, što svakako ima i prednosti i nedostatke). O raspravama oko medijskoga odgoja u obrazovanju vidi: Ciboci, L. (2012) Treba li medijski odgoj biti poseban predmet? Djecamedija.org. http://www.djecamedija.org/?p=1424 (pristupljeno: 5. prosinca 2017.); Galić, G. (2014) Medijski odgoj u škole. Vijenac 521. Matica hrvatska. http://www.matica.hr/vijenac/521/ medijski-odgoj-u-skole-22912/ (pristupljeno: 5. prosinca 2017.); HND (2017) Tribina o medijskoj pismenosti: Dvije trećine učenika želi medijski odgoj $u$ školama. H-alter. http://www.h-alter.org/vijesti/tribina-o-medijskoj-pismenosti-dvije-trecineucenika-zeli-medijski-odgoj-u-skolama; (pristupljeno: 5. prosinca 2017.); Kako bi se u školi trebalo učiti o medijima? (2017) Medijskapismenost.hr http://www.medijskapismenost.hr/kako-bi-se-u-skoli-trebalo-uciti-o-medijima/ (pristupljeno: 5. prosinca 2017.) 
potiče njihova kreativnost i kritičko razmišljanje i usvajanje novih sadržaja. Lana Ciboci je na jednak način upozorila: „Postojeći nastavni plan nije za odbaciti, no današnjim su učenicima potrebna dodatna znanja o medijima kako bi zajedno s njima mogli sigurno odrastati - uživajući u svim blagodatima koje oni pružaju, ali pazeći pritom na sve opasnosti na koje bi mogli naići. Od nas se očekuje da im pomognemo." (Ciboci, 2012) S Ciboci se slažu i Nadrljanski, Nadrljanski i Bilić koji kažu da se „budućnost obrazovnih sustava zasniva ... na sposobnosti za samoučenje - to je najvažniji element, a e-learning ima u tome značajnu ulogu“ (2007, str. 528).

Jadranka Žderić (2009, str. 17) je zaključila da je jedan od ključnih školskih zadataka, ali i neformalnih oblika obrazovanja, povezati različite medije i modernizirati današnju komunikaciju djece i mladih, $\mathrm{u}$ čemu veliku ulogu imaju nastavnici jer se moraju dodatno obrazovati kako bi djeci prenijeli znanja o medijima i pokazali im kako praktično implementirati medije u nastavu. Dodala je da je bitno „oblikovati nastavnike u medijatore 21. stoljeća koji pomažu da se određene sadržajne silnice prenesu pojedinim medijskim kanalima ne stavljajući ih u kalupe“ (Žderić, 2009, str. 22). U tom je kontekstu važno spomenuti i priručnik Preporuke za zaštitu djece i sigurno korištenje elektroničkih medija koji su izradili stručnjaci iz Agencije za elektroničke medije. Na sve popularnijoj internetskoj stranici Medijskapismenost.hr također se mogu naći savjeti o kvalitetnom i kreativnom uvođenju novih medija u nastavne, ali i izvannastavne aktivnosti. Na primjerima pozitivne prakse može se vidjeti da je primjena novih medija u nastavi itekako ostvariva, odnosno da su se dugogodišnji savjeti stručnjaka za uvođenjem medija kao alata u obrazovanju počeli provoditi i u hrvatskim školama.

Još 1987. Vladimir Mužić i Stjepan Rodek naglasili su potrebu za računalima u školama te dali vlastita originalna rješenja za nastavnu primjenu računala. Potaknut njihovim idejama, svoje je prijedloge dao i Branko Bognar, napisavši da „kompjutor omogućava primjenu različitih nastavnih strategija. Tako je moguće isti obrazovni sadržaj prezentirati putem programirane nastave, simulacija, igara i na druge načine“ (1991, str. 211). Takvo kombiniranje potiče dinamičnost i daje učeniku mogućnost odabira kako učiti (Bognar, 1991, str. 211). Svakako treba reći da se mediji toga doba razlikuju od današnjih, ali da im je zajednička jedna stvar, a to je njihova primjena u nastavi.

Marina Šimić (2016, str. 32) opisala je upotrebu digitalnih medijskih materijala u nastavi vjeronauka jer je i sama svjesna da se školovanje ne može odvijati bez tehnologije. Šimić svojim radom želi „pokazati kako se digitalni medijski materijali mogu primijeniti u 
određenim metodičkim sustavima kao posrednici dubljeg poniranja u sadržaj vjeronauka“ (2016, str. 32). I ne samo vjeronauka, već u svakom nastavnom predmetu pa tako i kada se govori o tradicijskoj kulturi, a to je ponajviše u nastavi glazbene kulture. Autorica u svome radu zaključuje:

„Različiti digitalni materijali oblikuju i različite mogućnosti izražavanja, ali ne moraju imati nužno pozitivan utjecaj. Njihovu primjenu potrebno je brižno planirati i to tako da oni budu element ili alat za ostvarenje ciljeva ... Ukoliko primjena digitalnih materijala nije efikasno metodički osmišljena, ona neće rezultirati željenim ishodima.... Zato je korisno češće poticati učenike na iznošenje vlastitog kritičkog mišljenja o pročitanom ili viđenom sadržaju. Da se ne bi izgubila riječ, a učenici ostali samo gledatelji kojima će tehnologija oduzeti sposobnost razmišljanja ... klasična metodička načela koja su prepoznata kao učinkovita ne treba napustiti, već samo nadopunjavati uporabom digitalnih medija." (Šimić, 2016, str. 38)

U knjizi Metodički aspekti obrade muzikoloških sadržaja: mediji u nastavi glazbe Sabina Vidulin-Orbanić i Lada Duraković (2012) cijelo jedno poglavlje posvetile su praktičnim aspektima korištenja medija u nastavi glazbe. Recenzentica njihove knjige, doc. dr. sc. Snježana Dobrota, piše kako autorice donose „opis načina i postupaka kojima je cilj obogaćivanje nastavnog procesa" (2012, str. 402). U knjizi se govori o primjeni vizualnih medija, mentalnih mapa, auditivnih i audiovizualnih medija, YouTubea i multimedije, a Dobrota je zaključila da autorice žele „prikazati načine konkretne primjene istih u nastavnoj praksi, povezujući nastavno gradivo“ (2012, str. 402). Tijana Vukić i Iva Youens napisale su članak Televizijski program kao nastavno sredstvo u stjecanju osnovnoškolskih medijskih kompetencija. Njihovo je istraživanje pokazalo da „70\% ispitanih nastavnika, iako u premaloj količini, koristi televiziju i njene sadržaje kao nastavno sredstvo i pomagalo. ... Preostalih 30 \% uopće ne upotrebljava taj masovni medij u realizaciji nastave" (Vukić, Youens, 2014, str. 91). Iako velik postotak nastavnika ima volju i spremnost za povećanje korištenja televizije u nastavi (njih $90 \%$ ), problem im predstavlja preopterećenost i preopširnost Nastavnoga plana i programa (Vukić, Youens, 2014, str. 92-93). S ciljem što češćeg korištenja televizije kao pomagala u učenju, ali i predmeta učenja, autorice su predložile sljedeće:

„... sustavno uvođenje stjecanja i razvoja medijskih kompetencija u sadržaj obveznih predmeta u obliku domaćih zadaća. Kombinacija upotrebe televizije i njenih sadržaja za izvršenje domaće zadaće dvostruko je opravdana: širi se znanje s jedne strane o predmetnoj 
tematici, a s druge o televiziji kao mediju i televizijskim sadržajima, istovremeno podižući razinu kvalitete nastavnog procesa, ali i medijskih kompetencija.“ (Vukić, Youens, 2014, str. 94)

Što se tiče primjene društvenih medija u nastavi, Matešić i suradnici su na temelju vlastitog istraživanja (2009, str. 9) utvrdili da se društveni mediji ne koriste onoliko koliko se to danas može očekivati premda su im ispitanici bili studenti i mlađi nastavnici. Problem su, prema njima, nastavnici koji nisu upoznati s mogućnostima društvenih medija kao nastavnog alata (2009, str. 9). Ariana Violić Koprivec i Jelena Dubčić zaključile su da studenti koriste Facebook većinom zbog zabave, ali da ga koriste u nastavi stranog jezika jer im tada pruža interaktivno, opuštajuće okruženje u kojem su u kontaktu s izvornim govornicima (2018, str. 82$)$.

Marta Čop i Velimir Topolovec napisali su rad o upotrebi informacijske i komunikacijske tehnologije (dalje IKT) u obrazovanju djece s posebnim potrebama. Autori su dali mnogo praktičnih savjeta o korištenju IKT alata, aplikacija i programa u obogaćivanju nastavnih sati učenika oštećena vida, tjelesnim invalidima i kronično bolesnim učenicima s Aspergerovim sindromom (Čop, Topolovec, 2009, str. 304-313). Naposljetku treba napomenuti kako raste broj diplomskih radova s temom primjene medija u nastavi, a iz kojih je vidljiv odnos učenika i nastavnika prema upotrebi novih tehnologija u obrazovanju (Cvetko, 2014; Činko, 2016; Čorak, 2018; Horvatić, 2017; Klarić, 2015).

\section{Djeca i folklor}

Kultura je bitan čimbenik društva, a poznata je u nekoliko oblika - elitnom, tradicionalnom, masovnom i digitalnom (Zgrabljić Rotar, 2017, str. 59). Tradicionalna je ona koja se veže uz narod i tradiciju, a naziva se folklornom ili narodnom kulturom (Hrvatska enciklopedija, mrežno izdanje). Zgrabljić Rotar (2017, str. 59) opisuje tu vrstu kulture kao onu koja se prenosi s koljena na koljena, koja ostaje u narodu, a podrazumijeva običaje, nošnje, glazbu i predmete. Ona podrazumijeva i književnost, plesove, dramski izraz te likovno stvaralaštvo (Hrvatska enciklopedija, mrežno izdanje), a odnosi se i na stvaralaštvo koje je utemeljeno na tradiciji neke kulturne zajednice, kojim se izražava kulturni i društveni identitet te zajednice. 
Djeca su činitelji zajednice pa ih se od malih nogu treba educirati o njihovoj tradiciji i kulturnoj baštini njihovih predaka. S obzirom na to da su svakodnevno okruženi novim medijima, tj. „internetskim sadržajima kojima možemo pristupiti putem računala, tableta i pametnih telefona “ (Ciboci, Kanižaj, Labaš, 2015), poželjno je djecu educirati na suvremen način o folkloru.

Projekt pod nazivom „Djeca čuvari baštine“ ${ }^{\text {“ }_{3}}$ održava se u dječjim vrtićima diljem Hrvatske (Dugo Selo, Zagreb, Zadar i Koprivnički Ivanec). Uporište za te projekte zasigurno je vezano uz knjigu Djeca - čuvari djedovine, Inge Seme-Stojnović i Tijane Vidović koji govori o modelu vrtića s hrvatskim identitetom i njegovanjem interkulturalnosti. ${ }^{4}$ područnom odjelu Cipelica Dječjeg vrtića Čakovec djeca i odgajateljice bave se identitetom zajednice koji se ostvaruje kroz kulturnu baštinu. Učenje o tradiciji i upotreba medija u edukaciji imaju gotovo jednake ciljeve kao i projekt „We are Europe“ o kojem pišu autorice članka „Prenošenje kultura povezivanjem“: poticanje razvoja djetetovog identiteta, poticanje suradničkog ponašanja, razvoj pozitivnih stavova i odnosa prema sebi i okolini, poticanje razvoja kreativnosti $u$ različitim oblicima izražavanja i stvaranja, razvoj socijalnih i komunikacijskih vještina te poticanje prosocijalnog ponašanja (Galinec i sur., 2012, str. 22). Premda Galinec i suradnici (2012, str. 23) pišu o fazama usvajanja znanja o kulturi, o odrastanju kroz teme mode, priča i mitova, pjesama, plesova, prehrane, igara, iz čega se vidi da pedagoški potiču djecu na istraživanje i uključivanje u rad, u članku nedostaje naglašena upotreba medija kao sredstva za prenošenje znanja i alata u edukaciji. Međutim, može se pretpostaviti da su oni korišteni s obzirom na to da se radi o novijem projektu, no svakako bi autorice trebale naglasiti i korištenje medija u kontekstu kulturne baštine, koja sve više poprima digitalne oblike ${ }^{5}$.

O tradicijskoj se kulturi uči u sklopu razredne nastave i Glazbene kulture prema aktualnom Nastavnom planu. Planom i programom obuhvaćene su sljedeće teme: narodna glazba, brojalice u udžbeniku, narodni plesovi i narodne nošnje. Anita Rončević i Marjan Blažić naglašavaju da se u kontekstu programa glazbene kulture „uopće ne spominje riječ multimedij“ (2009, str. 4). Jasna Šulentić Begić i Antonija Kaleb provele su istraživanje kojim su, između ostaloga, željele ispitati koja pomagala na satu koriste nastavnici

3 Više o projektu: https://www.bing.com/search?q=djeca+\%C4\%8Duvari+ba\%C5\%A1tine \&form=EDGNTT\&qs=PF\&cvid=6 38efa03f75843c49a84d877cb5774a9\&refig=1728396cc5844e54e1262d45fc1c76cc \&cc=HR\&setlang=hr-HR.

4 Za više literature o interkulturalnosti, baštini i mladima vidi: www.ucimohrvatski.com/index.php?view=article \&id=69\%3 Abatina\&format=pdf \&option=com content \&Itemid=57.

5 Digitalna kultura odnosi se na kulturu posredovanu elektroničkim medijima, kao i na oblik kulture koji je svojstven 21. stoljeću i prevladavajućoj IKT. Za više informacija, vidi: Zgrabljić Rotar (2011). 
glazbene kulture. Njihovo je istraživanje pokazalo da je najviše zastupljeno računalo $\mathrm{s}$ projektorom te prenosivi CD-player. Dječji instrumentarij manje je u upotrebi, a hi-fi linije gotovo da se i ne koriste. Televizija i DVD-i također nisu toliko zastupljeni (Šulentić Begić, Kaleb, 2012, str. 182). Očito je, dakle, da se mediji ne koriste dovoljno, a autorice se nadaju da tome nisu razlog vremenska ograničenost i nekomeptencije nastavnika, već ostavljaju pitanje otvorenim. Svakako bi bilo poželjno češće korištenje medija radi usvajanja glazbenih, ali i medijskih kompetencija. Dubravka Mitrović (2015) pisala je o folkloru kao izvanškolskoj aktivnosti, a Jurica Žibek u svom je diplomskom radu pisao o folklornim igrama i plesovima $\mathrm{u}$ razrednoj nastavi Glazbene kulture. Kao dodatak radu priložio je prijedlog priprave za izvođenje nastave Glazbene kulture. Žibek je, kako se čini, uspješno ukomponirao folklorni sadržaj u nastavni predmet. Autor je u prijedlogu svoje pripreme nastavnog sata Glazbene kulture naveo video snimke (Žibek, 2016, str. 53) kao jedini medij putem kojeg bi učenici upoznali temu sata, no u odjeljku o nastavnim pomagalima nije kao alat naveo nove medije. Da je naveo i nove medije kao nastavna pomagala, nacrt bi bio dobar primjer za multimedijalnu obradu nastavnog sadržaja.

U Okvirnome kurikulumu za predmet Kulturna i duhovna baština zavičaja urednice Jasenke Pregrad naglašena je uloga medija, kao predmeta i sredstva nastave, u podučavanju o kulturnoj baštini. Spominje se samo da „osim interneta, novine, televizija i radio također se mogu iskoristiti u radu za kulturnu i duhovnu baštinu zavičaja, posebno kada je riječ o projektima koji se realiziraju u suradnji s lokalnom zajednicom“ (Pregrad, 2006, str. 13). Konkretni savjeti, tj. primjeri nisu zapisani. Valja naglasiti kako prilikom istraživanja za potrebe pisanja ovoga rada (krajem 2017. godine) nije pronađen niti jedan rad koji na interdisciplinaran način pristupa formalnom (i neformalnom) obrazovanju djece u nižim razredima osnovne škole uz pomoć novih medija. No, 2018. bila je Europska godina kulturne baštine pa je u rujnu 2018. zajednica škola iz Europe i susjednih partnerskih država, eTwinning, objavila knjigu Učenjem iz prošlosti kreiramo našu budućnost: europska kulturna baština u eTwinningu, čiji su urednici Irene Pateraki i Santi Scimeca. Knjiga donosi čitavo poglavlje kako u nastavni sat o kulturnoj baštini uključiti medije kao alate, a temelji se na praktičnim savjetima. Prema svemu, u novijoj literaturi i dalje nedostaje priručnik koji detaljno i kvalitetno razrađuje i sugerira kako u obrazovanju o folkloru (baštini, tradiciji) upotrijebiti medije kao izvor za učenje, medije kao alate i prenositelje znanja, a ujedno i uređaje o kojima se uči dok ih se koristi. 


\section{Autorski volonterski projekt: Medijska radionica „e-follklor"}

Učenici četvrtog razreda osnovne škole Sveta Klara u školskoj godini 2015./2016. imali su priliku sudjelovati u medijskoj radionici. $\mathrm{S}$ obzirom na premalu satnicu, izvedba cjelokupnoga plana medijske radionice „e-folklor“ nije bila moguća, no uz organizaciju $\mathrm{s}$ učiteljicom Gorankom Tošaj Maceković ostvaren je jedan školski sat u sklopu sata dramske razredne sekcije u kojem su djeca usvojila nove folklorne informacije te naučila pjesmu koju su im otpjevali članovi dječje sekcije Kulturno-umjetničkog društva Bistra. Kreatorica i voditeljica radionice (autorica rada) ujedno je bila i članica toga KUD-a. U dogovoru s Marijom Bogdan, voditeljicom dječje sekcije, osmišljena je i putem mobilnog uređaja snimljena kratka te lako usvojiva koreografija uz narodnu pjesmu „Sejal mužek repu“. Taj je videouradak voditeljica radionice prikazala na satu putem školskog računala (video snimku prenijela je s mobilnog uređaja na računalo), a učenici su prema videouratku izveli pjevno-plesnu točku na nastavi.

Za provedbu radionice tijekom školske godine bile su predviđene sljedeće aktivnosti: gostovanje nekog KUD-a - učenje plesnih koraka uz učeničko snimanje prikazane koreografije nekim medijem; izrada folklorne „e-brošure“ s fotografijama prikupljenima s mreže „Pinterest“; izrada papirnate majice s etno motivima (ispisani motivi); izrada digitalne majice s etno motivima; usvajanje pjevno-plesne točke prema koreografiji koju bi pripremili članovi dječje sekcije nekog KUD-a; prikaz svega izrađenoga i naučenoga na godišnjoj školskoj priredbi uz snimanje priredbe te objavljivanje snimke (uz roditeljski pristanak) na naslovnici školske internetske stranice. U nastavku su prikazane samo neke stranice PowerPoint prezentacije iz kojih se može vidjeti kako je autorica provela ideju o spajanju novih medija i folklora (npr. upotrebom znaka \# karakterističnim za društvenu mrežu Instagram). 


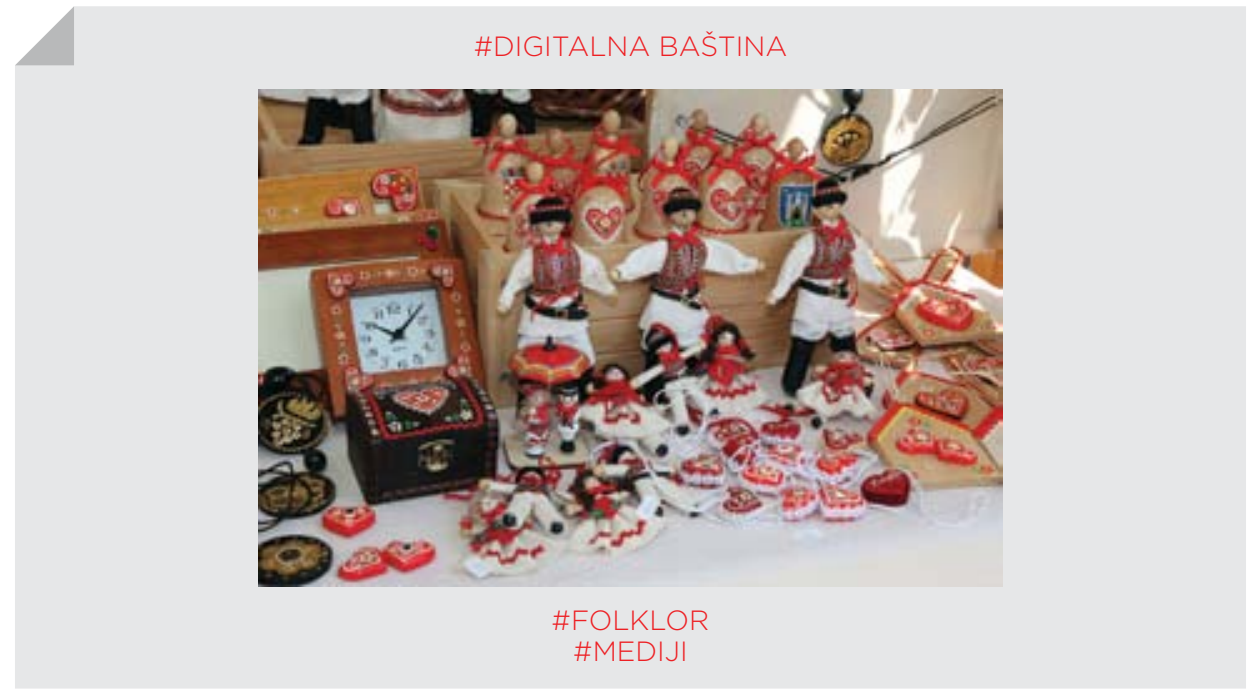

Slika 1. Naslovna stranica PowerPoint prezentacije

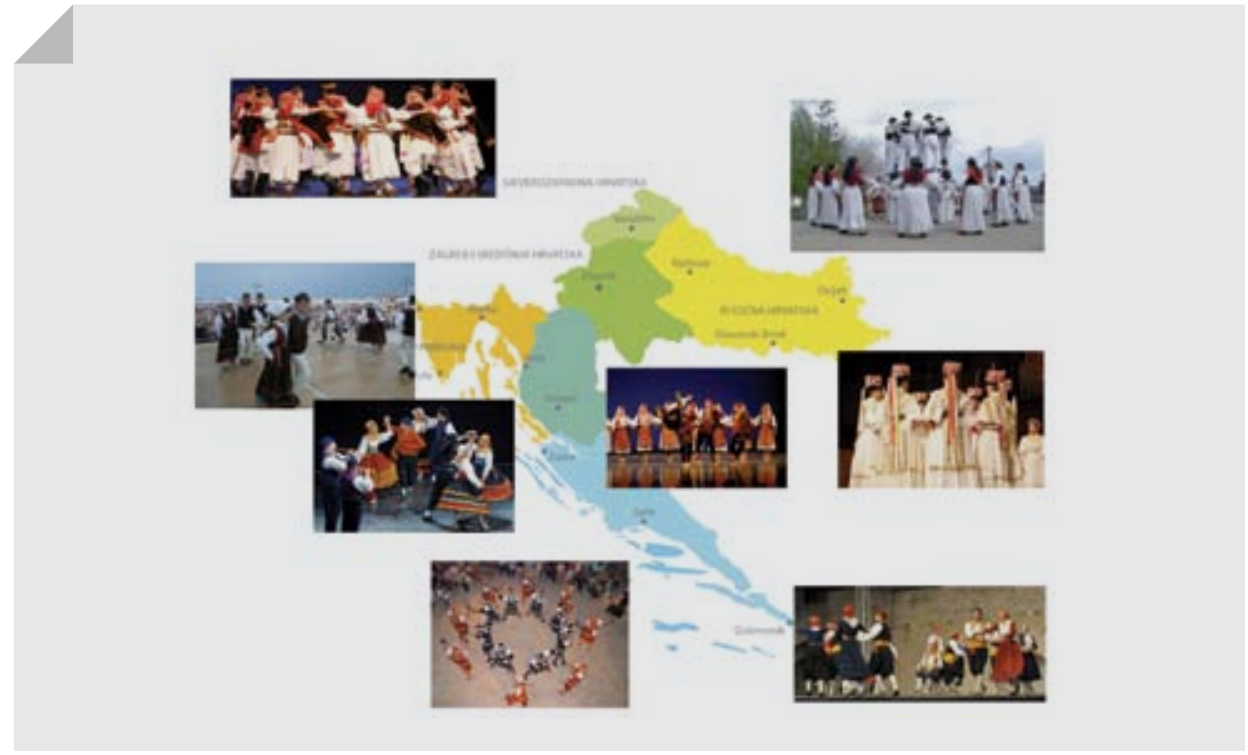

Slika 2. Stranica PowerPoint prezentacije o hrvatskim narodnim plesovima prema etnografskim zonama 
Druga prikazana stranica uključivala je i glazbenu podlogu koja se pokretala pojavljivanjem plesne slike iz određenog dijela Hrvatske, čime se na multimedijalan način željelo povezati karakterističan ples i nošnju s glazbom određenog geografskog područja RH (npr. kada se pojavila slika na kojoj ljudi odjeveni u konavosku nošnju plešu linđo, započeo je auditivni zapis linđa, s karakterističnim glazbalom, lijericom).

Opisanim primjerom (projektom) ostvarila se praktična primjena novih medija $u$ nastavi. Putem medija djeca su stekla nova znanja i usvojila nove vještine, ali su istovremeno učila i o medijima. Ova praksa upotrebe medija kao alata u nastavi i prenošenju kulturne baštine u skladu je i s Deklaracijom o medijskoj kulturi koju je 2012. godine donijelo Društvo za komunikacijsku i medijsku kulturu .

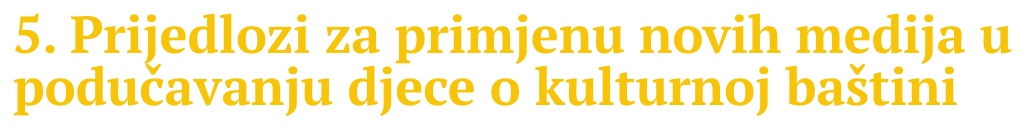

ZAGova reportaža o percepciji pojma „ETNO“, gdje se mogu vidjeti kadrovi u kojima djeca u učionicama rade od papira personaliziranu tradicijsku opravu, jedan je od primjera u kojem učenici uz pomoć medija stvaraju sadržaje kulturne tematike (Udruga ZAG, 2005). Svakako je poželjno da se sve aktivnosti koje se dotiču folklora opišu i uvrste u potencijalnu brošuru koja bi pomogla učiteljima i učenicima u učenju o baštini. Zato je prethodno poglavlje

6 Društvo za komunikacijsku i medijsku kulturu donijelo je 2012. godine Deklaraciju o medijskoj kulturi: „Svjesni sve važnije uloge medija u odgojno-obrazovnom životu djece i mladih, potaknuti primjerima država u kojima se djeca i mladi podučavaju važnosti i ulozi medija u našim životima, a temeljem preporuka Vijeća Europe, i UNESCO-a, potičemo pojedince i državne ustanove odgovorne za sadašnjost i budućnost djece i mladih da po uzoru na druge demokratske zemlje učine sve što je potrebno kako bi medijski odgoj i medijska kultura dobili zasluženo mjesto u hrvatskim osnovnim i srednjim školama, odgajatelje u vrtićima, nastavnike u osnovnim i srednjim školama da kod učenika razvijaju svijest o potrebi korištenja i kreiranja medijskih sadržaja, vrednovanja pozitivnih kao i kritičkoga odmaka od neprimjerenih, moralno neprihvatljivih, nasilnih i pornografskih sadržaja u tradicionalnim, a posebno novim medijima i društvenim mrežama, ravnatelje i članove Školskih odbora osnovnih i srednjih škola da osiguraju neophodne preduvjete za učitelje, pedagoge i psihologe kako bi mogli organizirati i provoditi radionice kao sastavni dio odgoja za medije, roditelje da pomognu djeci i mladima u odrastanju $s$ medijima, prateći njihovo sazrijevanje i pomažući im u razlučivanju dobroga od lošega, prihvatljivoga od neprihvatljivoga, i ukazujući im na potrebu razboritoga korištenja medija koje ne vodi u ovisnost, kao i da se sami educiraju o novim tehnologijama, djecu i mlade na usvajanje novih medijskih tehnologija, na kreativno korištenje medija u odgojne i obrazovne svrhe, da nove medije, posebno društvene mreže, koriste kao prostor prijateljstva, druženja i tolerancije, a ne kao prostor za širenje uvreda, laži i nasilnoga virtualnog ponašanja skrivajući se iza pseudonima, te da stvaraju i oblikuju medije i koriste ih za doprinos razvoju istinskoga čovjekoljublja i demokracije u društvu pridonoseći širenju slobode javne riječi, državne institucije, predstavnike Vlade, nadležnih ministarstava, saborske zastupnike i predstavnike lokalne samouprave da omoguće djeci i mladima pristup medijima, da dosljedno provode medijske zakone, i potaknu osnivanje Centra za istraživanje odnosa medija i djece te da potaknu razvoj sveučilišnih kurikuluma za obrazovanje medijskih pedagoga, medijske djelatnike, posebno glavne urednike i vlasnike tiskanih i elektroničkih medija na odgovorno ponašanje, poštivanje profesionalnih i etičkih standarda struke, osobito kada je riječ o izvještavanju o djeci, zaštiti njihova dostojanstva i poštivanju njihovih prava. Spremni smo pružiti ruku suradnje pojedincima, organiziranim skupinama, udrugama i ustanovama, svima koji se zauzimaju za bolju kvalitetu medijske kulture u javnom prostoru, kao i svima koji se zauzimaju za medijski odgoj i rad s mladima u hrvatskom društvu." (Dkmk.hr; 2012) 
poticaj za sve nastavnike da se educiraju i da vlastitim angažmanom upotrijebe medije, ali i poticaj za formiranjem udžbenika ili priručnika koji će na praktičnoj razini spojiti učenje o folkloru uz medije, ali i učenje o medijima uz folklor.

Ako se uzme u obzir da se o folkloru može učiti u raznim odgojno-obrazovnim institucijama, kao i uz medije, treba imati na umu da se i sve naučeno može uz medije i lakše usvojiti. Tako se može govoriti o modelu e-folklor, po uzoru na e-škole i e-imenike, u kojima se oznaka „„“ odnosi na digitalizirani pristup radu, a folklor je nastavna tema. Postavljajući folklor kao okosnicu, može se govoriti o dvjema razinama tradicijske kulture i novih medija u formalnom i neformalnom odgoju i obrazovanju djece - edukacija o tradicijskoj kulturi i edukacija i primjena znanja o tradicijskoj kulturi. Djeca i mladi mogu se educirati o tradicijskoj kulturi u nekoj od sljedećih institucija i putem medija.

Tablica 1. Primjeri za edukaciju o tradicijskoj kulturi

\begin{tabular}{|c|c|c|c|c|}
\hline Ustanove & \multicolumn{2}{|c|}{ Tradicionalni mediji } & \multicolumn{2}{|l|}{ Novi mediji } \\
\hline $\begin{array}{l}\text { 1. Etnografski } \\
\text { muzej Zagreb, } \\
\text { program za } \\
\text { škole } \\
\text { 2. Muzej } \\
\text { Međimurja } \\
\text { Čakovec }\end{array}$ & $\begin{array}{l}\text { Radio } \\
\text { Hrvatski radio, } \\
\text { emisije o kulturi: } \\
\text { Etno, fletno!, } \\
\text { Dubrovačka baština, } \\
\text { Baština, svijet i mi, } \\
\text { Priče iz života }\end{array}$ & $\begin{array}{l}\text { Televizija } \\
\text { HRT: } \\
\text { Školski sat } \\
\text { RTL: } \\
\text { Etno-sat }\end{array}$ & $\begin{array}{l}\text { Internetske stranice } \\
\text { Hrvatska enciklopedija } \\
\text { Leksikograf.zavoda } \\
\text { Miroslav Krleža, } \\
\text { mrežno izdanje } \\
\text { Etnoportal Lado, } \\
\text { Posudionica i radi- } \\
\text { onica narodnih nošnji }\end{array}$ & $\begin{array}{l}\text { Društvene mreže } \\
\text { YouTube, Facebook, } \\
\text { Instagram } \\
\text { (profili folklornih } \\
\text { ansambala } \\
\text { i kulturno- } \\
\text { umjetničkih } \\
\text { društava), Pinterest }\end{array}$ \\
\hline
\end{tabular}

Nakon što djeca usvoje znanje, također uz pomoć institucija mogu primijeniti stečeno znanje.

Tablica 2. Edukacija i primjena znanja o tradicijskoj kulturi

\begin{tabular}{|c|c|c|c|}
\hline $\begin{array}{l}\text { Folklorne } \\
\text { skupine u } \\
\text { vrtićima, } \\
\text { školama i } \\
\text { lokalnim } \\
\text { zajednicama }\end{array}$ & Etno-radionice & $\begin{array}{l}\text { Djeca i } \\
\text { folklor u } \\
\text { medijima }\end{array}$ & $\begin{array}{l}\text { Civilne } \\
\text { udruge }\end{array}$ \\
\hline $\begin{array}{l}\text { DV Petar Pan } \\
\text { Prva osnovna } \\
\text { škola Bjelovar } \\
\text { KUD „Bistra“ }\end{array}$ & $\begin{array}{l}\text { Dječji vrtići, škole, obrazovne institucije: } \\
\text { DV Markuševec, Narodno sveučilište „Sesvete“, } \\
\text { radionica izrade etno nakita, } \\
\text { Etnografski muzeji: Muzej Grada Đurđevca, } \\
\text { radionica o etno motivima, Narodni muzej Zadar } \\
\text { Lokalne i gradske knjižnice: Gradska knjižnica } \\
\text { Krapina, Knjižnice grada Zagreba, Etno radionice: } \\
\text { kako su igrale naše bake }\end{array}$ & $\begin{array}{l}\text { Projekt Drugi } \\
\text { djeca = autori } \\
\text { medijskog } \\
\text { etno-sadržaja } \\
\text { Lijepom } \\
\text { našom }\end{array}$ & $\begin{array}{l}\text { Udruga } \\
\text { ZAG } \\
\text { - dječja } \\
\text { reportaža } \\
\text { „Etno“ }\end{array}$ \\
\hline
\end{tabular}


Učenje o tradiciji, o kulturnome identitetu zajednice, promicanje baštine i očuvanje, a uz pomoć medija, svakako je nov, kreativan oblik usvajanja nastavnoga sadržaja koji je prožet tehnologijom te ga treba razvijati i njegovati. Jedna od mogućnosti za medijski pristup kulturnoj baštini jest uvođenje periodičnih radionica u sklopu sata razrednika u kojima bi se mogao provoditi teorijsko-praktični oblik nastave s fokusom na kulturnu baštinu, folklor i medije. U radu je prikazano da je takav oblik već teorijski i formiran, a proveden je čak i u praksi.

\section{. Zalključalk}

Rad je pokazao da se medije na zanimljiv način, uz educiranost i spremnost učitelja, itekako može uključiti u nastavni proces, s ciljem poticanja dječje kreativnosti i usvajanja znanja o novim medijima koji ih svakodnevno okružuju. Znanstvenici i stručnjaci već dvadesetak godina upozoravaju da smo okruženi medijima i da ih trebamo upoznati kako bismo se njima mogli kvalitetno koristiti.

Djeca četvrtoga razreda osnovne škole Sveta Klara u Zagrebu imala su priliku sudjelovati na medijskoj radionici „e-folklor“. Putem novih medija (računala i mobilnih uređaja) vidjeli su kako izgledaju hrvatske nošnje, čuli su tradicionalnu dječju pjesmicu i uočili tradicionalna glazbala. Uz pomoć članova dječje sekcije Kulturno-umjetničkoga društva Bistra, putem videouratka snimljenog mobilnim uređajem, učenici su usvojili kratku koreografiju koju su s veseljem izveli na nastavi. To je primjer pozitivne prakse upotrebe medija kao alata $\mathrm{u}$ nastavi. U radu su tako, s komunikološkog aspekta, opisani mediji kao izvor znanja, mediji kao posrednik u obrazovanju i mediji kao alat u kontekstu medijskoga obrazovanja.

Elektronički mediji mjesto su za edukaciju, primjenu stečenoga znanja i informiranje o etnozbivanjima. Na kraju se želi potaknuti nastavnike i edukatore da osnažuju dječju kreativnost i njihovu participaciju u upotrebi novih medija kao pomagala u nastavi, uče djecu o medijima, upotrebljavaju medije i pritom ukazuju na njihove pozitivne (i negativne) strane, usvajaju i čuvaju tradicijsku baštinu i otvore se s nove e-perspektive prema starinama. Takvim radom postiže se interdisciplinarnost u radu i sadržaju jer digitalnu kulturu 21. stoljeća može činiti spoj nastave, folklora i novih medija. Djeca i mladi uz pomoć medija mogu usvojiti i prenijeti znanje, a pritom se i zabaviti.

\section{Popis literature}

- Agencija za elektroničke medije (2016). Preporuke za zaštitu djece i sigurno korištenje elektroničkih medija. Dostupno na: http://www. medijskapismenost.hr/wp-content/uploads/2016/09/medijska-pismenost-preporuke-dokument.pdf. Preuzeto 18. siječnja 2018.

- Bognar, B. (1991). Kompjutor u učionici, 211-216. U: V. Puževski (ur.), U potrazi za suvremenom osnovnom školom. Zagreb: Institut za pedagogijska istraživanja Filozofskog fakulteta Sveučilišta u Zagrebu; Katehetski salezijanski centar.

Ciboci, L. (2012). Treba li medijski odgoj biti poseban predmet? Dostupno na: http://www.djecamedija.org/?p=1424. Preuzeto 5. prosinca 2017. 
- Čop, M., Topolovec, V. (2009). Upotreba informacijske i komunikacijske tehnologije (ict) u obrazovanju djece s posebnim potrebama. Informatologia, 42 (4), 304-313.

- Dobrota, S. (2012). Metodički aspekti obrade muzikoloških sadržaja - Mediji u nastavi glazbe. Školski vjesnik, 61 (3), $401-402$.

- Erjavec, K., Zgrabljić Rotar, N. (2000). Odgoj za medije u školama u svijetu. Hrvatski model medijskog odgoja. Medijska istraživanja, 6 (1), 89-107.

- Galić, G. (2014). Medijski odgoj u škole. Dostupno na: http://www.matica.hr/vijenac/521/medijski-odgoj-u-skole-22912/. Preuzeto 5. prosinca 2017.

- Galinec, M., Vlahek, T., Lozić, B., Novak, M., Goričanec, G., Zuzel, P., Nemet, S. (2012). Prenošenje kultura povezivanjem. Dijete, vrtić, obitelj: Časopis za odgoj i naobrazbu predškolske djece namijenjen stručnjacima i roditeljima, 18 (67), 22-25.

- Hrvatska enciklopedija, mrežno izdanje (n.p.). Natuknice: folklor, kulturna baština, nastava, novi mediji. Dostupno na: http:// www.enciklopedija.hr/. Preuzeto 1. prosinca 2017.

- Hrvatsko novinarsko društvo (2017). Tribina o medijskoj pismenosti: Dvije trećine učenika želi medijski odgoj u školama. Dostupno na: http://www.h-alter.org/vijesti/tribina-o-medijskoj-pismenosti-dvije-trecine-ucenika-zeli-medijski-odgoj-u-skolama. Preuzeto 5. prosinca 2017.

- Košir, M., Zgrabljić N., Ranfl, R. (1999). Život s medijima - Priručnik o medijskom odgoju za roditelje, nastavnike i učitelje. Zagreb: Doron. - Jeričić, M., Sitar, J. (2014).Medijska pismenost: Uloga medija u razvoju djece. Dostupno na: http://junior.24sata.hr/zanimljivosti/ medijska-pismenost-uloga-medija-u-razvoju-djece-365576. Preuzeto 5. prosinca 2017.

- Labaš, D., Ciboci, L., Kanižaj, I. (2015). Mediji (i) naši učitelji (edukativna brošura). Zagreb: Društvo za komunikacijsku i medijsku kulturu.

- Matešić, M. i sur. (2009). Social Software: Teaching Tool or Not?, INFuture2009: Digital Resources and Knowledge Sharing. Dostupno na: https://bib.irb.hr/datoteka/433059.MM_KV_ZD-IN_Future.pdf. Preuzeto 28. siječnja 2019.

- Medijskapismenost.hr. (2017). Kako bi se u školi trebalo učiti o medijima? Dostupno na. http://www.medijskapismenost.hr/ kako-bi-se-u-skoli-trebalo-uciti-o-medijima/. Preuzeto 18. siječnja 2018.

- Ministarstvo obrazovanja, znanosti i športa (2006) Nastavni plan i program za osnovnu školu: Glazbena kultura. Dostupno na: https://www.azoo.hr/images/AZOO/Ravnatelji/RM/Nastavni_plan_i_program_za_osnovnu_skolu___MZOS_2006_pdf. Preuzeto 5. prosinca 2017.

- Mitrović, D. (2015). Folklorni ples kao izvanškolska aktivnost učenika primarnog obrazovanja (diplomski rad). Osijek: Sveučilište u Osijeku.

- Mužić, V., Rodek, S. (1987). Kompjutor u preobražaju škole. Zagreb: Školska knjiga.

- Nadrljanski, M., Nadrljanski, Đ., Bilić, M. (2007). Digitalni mediji u obrazovanju, 527-537. U: Seljan, S., Stančić, H. (ur.), INFuture 2007: Digital information and heritage. Zagreb: Filozofski fakultet, Sveučilište u Zagrebu.

- Osmančević, L. (2016). Mediji u odgoju i obrazovanju, 76-83. U: Vejmelka, L., Vuga, A., Radat, K. (ur.), Zbornik radova 2. konferencije prevencije ovisnosti: alkoholizam, ovisnost o drogama i novije ovisnosti i 1. ljetne škole modernih tehnologija. Zagreb: Društvo za socijalnu podršku.

- Pateraki, I., Santi Scimeca, S. (2018). Učenjem iz prošlosti kreiramo našu budućnost: europska kulturna baština u eTwinningu. Središnja služba za podršku eTwinning-u www.etwinning.net.

- Rončević, A., Blažič, M. (2009). Mediji u koncepciji nastavnog rada učitelja u osnovnim školama. Dostupno na: https://bib.irb.hr/ datoteka/471033.Zadar09.pdf. Preuzeto 5. prosina 2017.

- Seme-Stojnović, I., Vidović, T. (2012). Djeca - čuvari djedovine : model vrtića s hrvatskim identitetom i njegovanjem interkulturalnosti: priručnik za odgojitelje, učitelje, roditelje, manjine, iseljenike - građane svijeta. Zagreb: Golden marketing - Tehnička knjiga.

- Šuletnić Begić, J., Kaleb, A. (2012). Planiranje i programiranje nastave glazbene kulture u prvi tri razreda osnovne škole. Život i škola: časopis za teoriju i praksu odgoja i obrazovanja, LVIII (28), 168-186.

- Udruga ZAG. (2005). 6. ETNO REPORTAŽA. Dostupno na: https://udrugazag.hr/6-etno-reportaza/. Preuzeto 5. prosinca 2017.

- Vidulin-Orbanić, S., Duraković, L. (2012) Metodički aspekti obrade muzikoloških sadržaja: mediji u nastavi glazbe: sveučilišni udžbenik. Pula: Sveučilište Jurja Dobrile, Odjel za glazbu.

- Violić Koprivec, A., Dubčić, J. (2018). Facebook kao obrazovni alat u nastavi stranih jezika. MediAnali, 12 (15), 69-84.

- Vukić, T., Younes, I. (2015). Televizijski program kao nastavno sredstvo u stjecanju osnovnoškolskih medijskih kompetencija. Medijska istraživanja, 21 (1), 79-101.

- Zgrabljić Rotar, N. (ur.) (2005). Medijska pismenost i civilno društvo. Sarajevo: Mediacentar.

- Zgrabljić Rotar, N. (ur.) (2011). Digitalno doba: masovni mediji i digitalna kultura. Zadar: Sveučilište u Zadreu, Zagreb: Naklada Medijska istraživanja d.o.o.

- Zgrabljić Rotar, N. (2017). Novi mediji digitalnog doba, 57-64. U: Lj. Josić, LJ. (ur.), Zbornik Informacijska tehnologija i mediji 2016. Zagreb: Hrvatski studiji Sveuĉilišta u Zagrebu.

- Žderić, J. (2009). Medijska kultura djece i mladih: mogućnosti i zamke. Zagreb: Medioteka.

- Žibek, J. (2016). Folklorne igre i plesovi u nastavi glazbene kulture od 1. - 4. razreda (diplomski rad). Zagreb: Sveučilište u Zagrebu. 


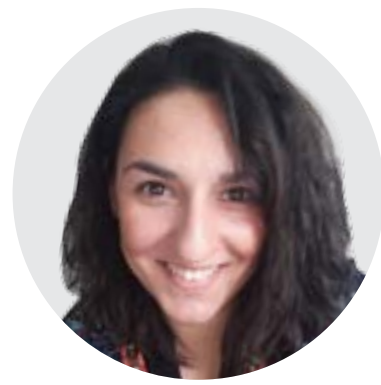

\section{Lina Malek}

Lina Malek rođena je 1992.

$\mathrm{u}$ Zagrebu. Na Hrvatskim studijima Sveučilišta u Zagrebu diplomirala je komunikologiju i kroatologiju. Sudjelovala je $\mathrm{u}$ Erasmus studentskoj razmjeni pri Institutu za slavistiku Sveučilišta u Heidelbergu, u Njemačkoj. U ljetnom semestru ak. god. 2017./2018. bila je vanjska suradnica na kolegiju „Akademska pismenost“ na Hrvatskim studijima. Od prosinca 2018. doktorandica je na poslijediplomskom studiju kroatologije. Dobitnica je Rektorove nagrade za društveno koristan rad u akademskoj i široj zajednici, Stipendije za izvrsnost Sveučilišta u Zagrebu i Priznanja voditelja Hrvatskih studija. Sudjelovala je kao izlagačica na dvama znanstvenim kolokvijima u organizaciji Društva studenata kroatologije Cassius. Aktivna je članica Društva za komunikacijsku i medijsku kulturu i Udruge

Ekomuzej Bistra. 